\title{
Kemampuan Spasial dalam Pengkonstruksian Jaring-Jaring Kubus dan Balok
}

\author{
Shinta Wulandari
}

(C) 2019 JEMS (Jurnal Edukasi Matematika dan Sains)

This is an open access article under the CC-BY-SA license (https://creativecommons.org/licenses/bysa/4.0/) ISSN 2337-9049 (print), ISSN 2502-4671 (online)

\begin{abstract}
Abstrak:
Jaring-jaring dapat membantu siswa membuat konsep hubungan antara objek dua dimensi dan tiga dimensi. Namun masih ada ketidakakuratan dalam menyusun jaring-jaring yang disebabkan oleh kemampuan spasial yang lemah. Tujuan dari penelitian ini adalah untuk menggambarkan kemampuan spasial siswa dalam membangun jaring-jaring kubus dan balok. Subjek penelitian adalah empat puluh siswa Sekolah Dasar kelas lima. Dari empat puluh siswa dipilih dua siswa untk diwawancara lebih mendalam terkait penyelesaian tugas jaring-jaring kubus dan balok. Hasil penelitian menunjukkan bahwa dalam menyelesaikan tugas penyusunan jaring-jaring kubus dan balok, subjek menunjukkan kelemahan dalam kemampuan orientasi spasial dan visualisasi spasial. Kelemahan pada orientasi spasial terlihat pada kemampuan subjek untuk melihat objek dari sudut pandang tertentu yaitu dalam mengenali dua jaring-jaring yang kongruen tetapi dianggap tidak kongruen. Sedangkan kelemahan visualisasi spasial nampak pada saat subjek yang tidak dapat membayangkan bahwa jaring-jaring dapat dilipat menjadi kubus dan balok.
\end{abstract}

Kata Kunci : Kemampuan Spasial, Jaring-jaring kubus, konstruksi

\section{Pendahuluan}

Geometri merupakan cabang ilmu Matematika yang mempelajari tentang bentuk dimensi dua dan dimensi tiga. Konsep yang dipelajari pada keduanya saling berkaitan, salah satunya adalah konsep jaring-jaring. Jaring-jaring merupakan bentuk dua dimensi yang dapat dilipat menjadi bangun dimensi tiga (Jeon, 2009). Mempelajari jaring-jaring dapat membantu siswa dalam membuat koneksi antara bangun dimensi dua dengan dimensi tiga. Dalam memahami konsep jaring-jaring diperlukan keterampilan kognitif yang berkaitan dengan ruang yaitu kemampuan spasial. Kemampuan spasial adalah kemampuan seseorang untuk memvisualisasi-

Shinta Wulandari, Universitas Borneo Tarakan

pmatshintaw@gmail.com

\begin{abstract}
:
Nets can help students conceptualize the relationship between two-dimensional and three-dimensional objects. But there are still inaccuracies in composing the webs caused by weak spatial ability. The purpose of this study is to describe the spatial ability of students in constructing cube and beam webs. The research subjects were forty-fifth-grade elementary school students. Of the forty students, two students were chosen to be interviewed more deeply related to the completion of the task of the cube nets and the beam. The results showed that in completing the task of arranging cube and beam nets, the subject showed weaknesses in the ability of spatial orientation and spatial visualization. Weaknesses in spatial orientation are seen in the subject's ability to see objects from a certain point of view, namely in recognizing two nets that are congruent but considered incongruent while the weaknesses of spatial visualization are seen when subjects cannot imagine that the webs can be folded into cubes and blocks.
\end{abstract}

Keywords : Spatial ability; cube nets; construction 
kan gambar atau menciptakannya dalam bentuk dua atau tiga dimensi (Gecu \& Erkoc, 2015; Hegarty \& Waller, 2004). Seseorang yang memiliki kecerdasan spasial tinggi cenderung mudah belajar melalui sajian-sajian visual. Kemampuan spasial yang baik akan menjadikan siswa mampu mendeteksi hubungan dan perubahan bentuk bangun dalam geometri. Melalui kemampuan dan penginderaan spasial, akan sangat berguna dalam memahami relasi dan sifatsifat objek spasial dalam geometri untuk memecahkan baik masalah matematika maupun masalah dalam kehidupan sehari-hari (Wai, dkk, 2009). Hasil penelitian menunjukkan bahwa kemampuan spasial terbukti dapat mendukung karis seseorang pada bidang Sains, Teknik, dan Matematika (Wai, dkk, 2009; Wakabayashi \& Ishikawa, 2011).

Kemampuan spasial tediri dari tiga komponen yaitu visualisasi spasial, relasi spasial dan orientasi spasial (Wakabayashi \& Ishikawa, 2011; Yilmaz, 2009). Visualisasi spasial merupakan kemampuan dalam memanipulasi secara mental pergerakan suatu objek spasial. Orientasi spasial merupakan kemampuan dalam membayangkan suatu objek spasial dari sudut pandang tertentu. Relasi spasial merupakan kemampuan dalam membuat hubungan antar objek spasial. Ketiga komponen tersebut diperlukan saat siswa mengkontruksi jaring-jaring.

Pengonstruksian jaring-jaring merupakan salah satu tipe penalaran dalam berpikir geometris pada objek 3D (Pittalis \& Christou: 2010). Dalam pengonstruksian jaring-jaring diperlukan kemampuan siswa dalam membuat translasi dari bentuk 3D ke bentuk 2D dengan memperhatikan bagian dan komponen dari objek yang akan dikonstruk jaring-jaringnya. Komponen dari objek berupa jumlah unit satuan sebagai pembentuk jaring-jaring, susunan unit sehingga konstruksi yang dibuat dapat membentuk objek 3D dan kontruksi antar jaring-jaring bersifat tidak kongruen.

Kemampuan spasial diperlukan dalam belajar geometri (Mix, dkk, 2016; Cohen \& Hegarty, 2012). Namun terdapat siswa yang memiliki kelemahan dalam kemampuan spasialnya. Penelitian ini bertujuan untuk mengeksplorasi bagaimana siswa kelas lima sekolah dasar mengkonstruk jaring-jaring. Fokus penelitian yaitu pada kemampuan spasial siswa pada saat diberi tugas menyusun jaring-jaring kubus dan balok.

\section{Metode}

Penelitian ini merupakan penelitian studi kasus tipe instrumental, karena penelitian ini fokus pada pemahaman individu yang diberikan tugas mengonstruksi jaring-jaring kubus dan balok (Fraenkel, dkk, 2012; Cresswell, 2012). Subjek terdiri dari dua siswa kelas lima sekolah dasar di Kota Malang. Subjek dipilih dari 40 siswa yang melakukan serangkaian tugas geometri yang dirancang guru. Berdasarkan hasil penyelesaian tugas tersebut dilakukan pemilihan subjek. Subjek dipilih dengan mempertimbangkan kemampuan spasial yang baik, nilai capaian akademik serta kemampuan siswa dalam berkomunikasi. Subjek yang terpilih diminta untuk menyelesaikan tugas penyusunan jaring-jaring kubus dan balok. Pemberian tugas dilakukan pada waktu yang berbeda.

Subjek diwawancarai untuk mengkonfirmasi hasil pekerjaannya serta menggali kemampuan spasialnya saat menyelesaikan tugas penyusunan jaring-jaring kubus dan balok (Cresswell, 2012). Wawancara dilakukan beberapa saat setelah subjek menyelesaikan tugas yang diberikan. Pada tugas pertama, subjek diminta mengonstruksi jaring-jaring kubus dengan menggunakan media berupa potongan-potongan persegi dengan warna yang sama. Hasilnya ditempel pada kertas kerja yang telah disediakan. Tugas kedua yaitu mengonstruksi jaring-jaring balok menggunakan media berupa persegi panjang berwarna-warni yang dapat digunakan 
subjek untuk mengkonstruk jaring-jaring balok. Hasil konstruksi tugas kedua direpresentasikan dalam bentuk sketsa gambar pada kertas yang telah tersedia. Data yang diperoleh kemudian dianalisis dengan terlebih dahulu melakukan pengkodean. Pengkodean dilakukan untuk menangkap kejadian-kejadian terkait komponen kemampuan spasial. Selanjutnya kode-kode dideskripsikan atau diinterpretasikan (Cresswell, 2012).

\section{Hasil dan Pembahasan}

Pada bagian ini didiskusikan hasil penelitian yang berkaitan dengan tujuan penelitian yaitu mendeskripsikan konstruksi jaring-jaring kubus dan balok dari perspektif kemampuan spasial. Dua subjek pada penelitian diberi kode S1 untuk subjek pertama dan S2 untuk subjek kedua. Kedua subjek merupakan siswa dengan kemampuan matematika tinggi serta memiliki kemampuan komunikasi yang baik.

1. Konstruksi Jaring-jaring Kubus

Tugas pertama yang diberikan adalah menemukan konstruksi kubus yang berbeda sebanyak mungkin dengan menggunakan media potongan berbentuk persegi. Media yang disediakan terdiri dari satu warna dan disediakan sebanyak enam puluh unit.

Kedua subjek S1 dan S2 menyusun jaring-jaring kubus sebanyak tujuh dari sebelas jaringjaring yang kongruen. Dari ketujuh jaring-jaring tersebut S1 menyusun 6 jaring-jaring tidak kongruen dan terdapat satu jaring-jaring yang merupakan jaring-jaring yang kongruen dengan satu jaring-jaring lainnya. Kekongruen dua jaring-jaring kubus dapat dilihat pada Gambar 1. Sedangkan subjek S2 menyusun jaring-jaring kubus sebanyak tujuh, enam diantaranya merupakan jaring-jaring yang tidak kongruen dan satu jaring-jaring merupakan jaring-jaring dengan tujuh unit persegi.

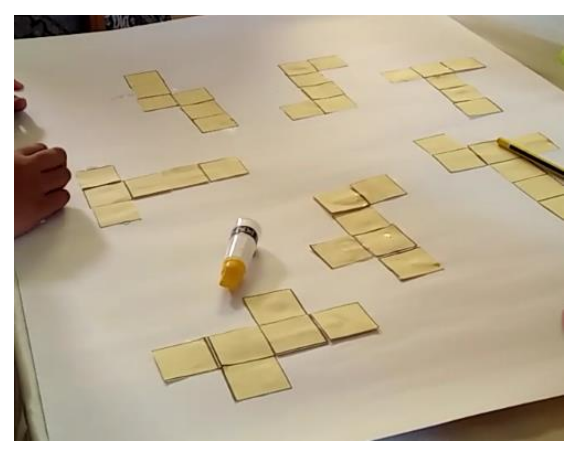

Gambar 1. Dua jaring-jaring yang kongruen tetapi dianggap tidak kongruen

Pada saat memulai mengonstruksi jaring-jaring, S1 dan S2 mengambil beberapa persegi. Kemudian menyusunnya sedemikian rupa pada media kertas. Setelah menyusun unit persegi, keduanya mulai mengecek secara mental apakah konstruksi yang dibuat dapat membentuk kubus atau tidak. Ketika melakukan pengecekan secara mental, ditandai dengan gerakan tangan yang menggambarkan pergerakan unit-unit persegi yang seolah-olah dilipat pada posisi tertentu (Cohen \& Hegarty: 2012). Aktifitas ini menggambarkan kemampuan subjek dalam visualisasi spasial (Hegarty \& Waller: 2004; Yilmaz: 2009); Hawes, dkk: 2015). Melalui kemampuan dalam visualisasi spasial subjek dapat memastikan apakah jaring-jaring yang telah dikonstruksi dapat membentuk kubus atau tidak (Jeon: 2009). 
Berdasarkan hasil representasi jaring-jaring kubus melalui gambar, selanjutnya digali informasi lebih mendalam untuk memperoleh informasi terkait kemampuan spasial siswa. Berikut hasil wawancara untuk menggali kemampuan visualisasi spasial:

S1 : pertama saya ambil 6 persegi... kemudian menyusun seperti ini...

Obs : mengapa yang diambil 6 persegi?

S1 : (berhenti sekitar 30 detik) karena sisi kubus ada enam

Subjek S1 mengatakan bahwa untuk membentuk jaring-jaring kubus diperlukan persegi satuan sebanyak enam unit. Lebih lanjut S1 mengatakan bahwa enam persegi tersebut diperoleh dari banyaknya sisi pada kubus. Pada saat menyusun jaring-jaring yang kelima, S2 menyusun persegi sebanyak tujuh unit. Gambar 2 menunjukkan bahwa konstruksi jaring-jaring kubus menggunakan unit persegi sebanyak tujuh unit. Ketika dikonfirmasi mengenai hal tersebut, S2 mengatakan bahwa pada saat menyusun dia hanya memperhatikan bahwa konstruksi tersebut memungkinkan untuk dilipat menjadi kubus. Subjek S2 tidak lagi mempertimbangkan bahwa jumlah persegi satuan menentukan suatu jaring-jaring dapat membentuk kubus atau tidak. Hal tersebut didukung oleh hasil wawancara sebagai berikut :

Obs : Bagaimana cara mendapatkan jaring-jaring yang kelima?

S2 : Oh...itu... sama dengan jaring-jaring sebelumnya

Obs : Bagaimana?

S2 : saya ambil persegi, kemudian disusun, sudah

Obs : apa itu membentuk kubus jika dilipat?

S2 : (tangan memperagakan potongan persegi yang terlipat)... iya bisa.

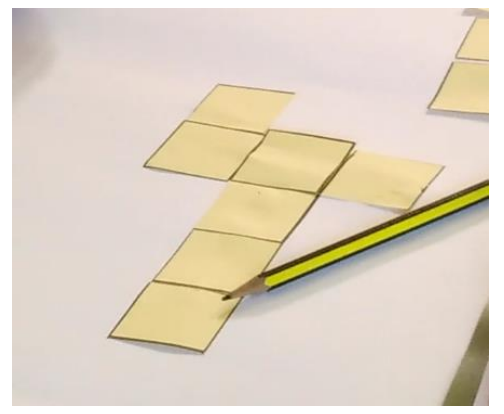

Gambar 2. Konstruksi jaring-jaring kubus dengan persegi sebanyak tujuh unit

Jaring-jaring kubus satu demi satu disusun oleh kedua subjek. Untuk mengonstruksi jaring-jaring diperlukan pengetahuan tentang konsep kekongruenan antar jaring-jaring kubus (Jeon, 2009). Subjek S1 dan S2 melakukan pengecekan antar jaring-jaring kubus dengan membandingkan antar jaring-jaring kubus yang telah dibuat sebelumnya. Subjek S1 mengatakan bahwa dia melakukan pengecekan kekongruenan dengan membandingkan antar jaring-jaring yang dibuatnya. Dia menjelaskan, jika terdapat dua jaring-jaring yang kongruen, maka akan dipilih salah satu dan jaring-jaring yang tidak dipilih akan dikonstruksi kembali. Aktivitas tersebut merupakan aktivitas yang menggunakan kemampuan relasi spasial (Wai, dkk, 2009; Yilmaz, 2009; Hawes, dkk, 2015). 
Pengecekan kekongruenan jaring-jaring kubus juga dipertimbangkan dari jaring-jaring yang dilihat dari sudut pandang yang berbeda. Dua jaring-jaring dikatakan kongruen jika merupakan hasil perputaran dari salah satu dari dua jaring-jaring tersebut (Jeon: 2009). Gambar 1 menunjukkan bahwa S1 tidak menyadari bahwa terdapat dua jaring-jaring yang salah satunya merupakan perputaran dari jaring-jaring lainnya. Dalam hal ini S1 memiliki kelemahan dalam orientasi spasial (Wai, dkk, 2009; Yilmaz, 2009; Hawes, dkk, 2015).

2. Konstruksi Jaring-jaring Balok

Setelah melakukan aktivitas penyusunan jaring-jaring kubus, selanjutnya kedua subjek diberikan tugas pengonstruksian jaring-jaring balok. Skenario pada tugas kedua yaitu siswa diminta untuk merepresentasikan jaring-jaring yang dikonstruksi dalam bentuk gambar. Untuk membantu siswa dalam mengonstruksi, disediakan persegi panjang sebanyak dua belas pieces dengan warna yang berbeda.

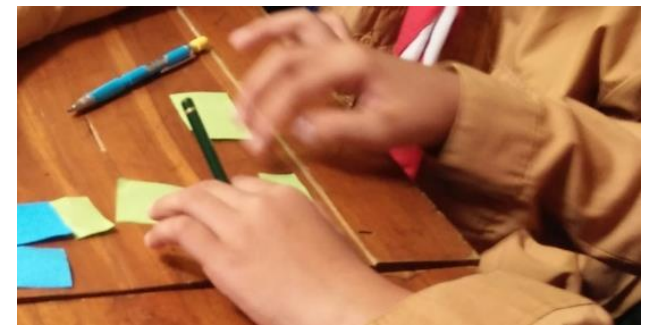

Gambar 3. Pengkonstruksian Jaring-jaring Balok

Gambar 3 mendeskripsikan kinerja S2 dalam menyusun jaring-jaring balok yang memerlukan bantuan media berupa potongan kertas berbentuk persegi panjang. Dengan menyusun sedemikian rupa, subjek dapat membayangkan konstruksi yang dibuat dapat membentuk balok atau tidak. Dalam hal ini subjek menggunakan pendekatan imajistik yaitu ditandai dengan adanya aktivitas pengkodean, membayangkan yang ditandai dengan gerakan tangan yang mewakili pergerakan unit persegi panjang serta representasi berupa sketsa jaringjaring (Cohen \& Hegarty: 2012; Koyunkaya: 2016).

Dari tugas pengkonstruksian jaring-jaring kubus, nampak kedua subjek mengalami kesulitan. Hal ini disampaikan kedua subjek pada saat wawancara bahwa pengonstruksian balok lebih sulit daripada penyusunan jaring-jaring kubus. Berikut wawancara dengan S1:

Obs : bagaimana Anda mengkonstruk jaring-jaring balok ini

S1 : susah ... saya bayangkan seperti jaring-jaring kubus kemudian yang persegi saya ubah menjadi persegi panjang

Obs : : mengapa sulit

S1 : : karena pada balok sisi-sisinya tidak sama seperti kubus

Obs : maksudnya?

S1 : ada tiga pasang dan tiap pasang ukurannya tidak sama

Subjek S1 memberikan alasan bahwa balok disusun dari enam persegi panjang dimana pada saat menyusun menjadi balok harus disesuaikan panjang sisi pada unit persegi panjang. Dalam hal ini kesesuaian dilihat dari panjang sisi berimpit yang sama panjang dan posisi unit persegi panjang. Subjek S2 menambahkan bahwa dalam pengonstruksian jaring-jaring balok, terdapat enam persegi panjang terdiri dari tiga pasang persegi panjang. 
Strategi yang dipilih S1 dan S2 pada pengonstruksian jaring-jaring balok adalah dengan mengaitkannya dengan jaring-jaring kubus. Konstruksi yang pernah disusun pada kubus mereka terapkan pada balok dengan menyesuaikan bentuk dimensi duanya yaitu dari persegi menjadi persegi panjang. Subjek S1 menyampaikan bahwa dia awalnya melukis satu jaring-jaring kubus, kemudian menggantinya dengan persegi panjang. Berdasarkan Gambar 4, nampak bahwa S1 lemah dalam kemampuan visualisasi dan relasi spasial. Kelemahan visualisasi spasial nampak pada konstruksi yang direpresentasikan dimana jaring-jaring balok tersebut jika dilipat sedemikian rupa tidak membentuk balok. Subjek S1 tidak memperhatikan sisi-sisi yang berimpit antar unit persegi panjang. Selama pengonstruksian jaring-jaring balok, S1 menggunakan bayangan mental tidak menggunakan media persegi panjang yang telah disediakan. Subjek S1 beralasan bahwa tugas ini mirip dengan jaring-jaring kubus sehingga memutuskan untuk tidak menggunakan media persegi panjang.

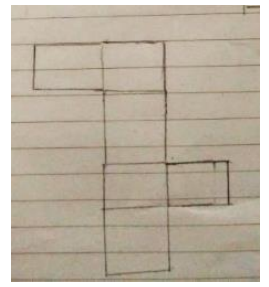

Gambar 4. Representasi jaring-jaring balok oleh S1

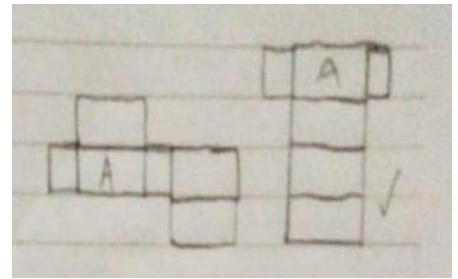

Gambar 5. Representasi jaring-jaring balok oleh S2

Gambar 5 menunjukkan kinerja S2 pada pengonstruksian jaring-jaring balok. Subjek S2 memberikan simbol A untuk menunjukkan bahwa bagian tersebut merupakan alas dari balok yang dibentuk dari jaring-jaring tersebut. Representasi dari S2 diperoleh dengan bantuan media persegi panjang yang disediakan. Namun pada saat merepresentasikan dalam bentuk gambar, nampak bahwa S2 tidak memperhatikan sisi-sisi persegi panjang yang pada saat dilipat akan membentuk rusuk balok meskipun pada saat menyusun jaring-jaring menggunakan media persegi panjang. Unit-unit persegi panjang yang dia susun nampak merupakan konstruksi jaringjaring balok yang benar. Panjang sisi persegi panjang tersebut seharusnya memiliki panjang sisi yang sama. Untuk memperoleh informasi tambahan, dilakukan wawancara sebagai berikut:

Obs : bisakah anda jelaskan bahwa jaring-jaring yang pertama dapat membentuk balok?

S2 : itu terlihat dari jumlah persegi panjangnya ada enam, sama dengan sisi balok

Obs : bisakah dengan sketsa ini nanti bisa membentuk balok?

S2 : (melakukan depicted hand sekitar 30 detik) bisa

Obs : : kenapa kok bisa?

S2 : kan dilipat seperti ini (diwakili oleh gerakan tangan), jumlahnya enam dan sudah persegi panjangnya sudah pas posisinya

Dalam hal ini S2 memiliki kelemahan dalam kemampuan relasi spasial (Wai, dkk: 2009; Yilmaz: 2009; Hawes, dkk: 2015). Dengan representasi seperti Gambar 4 nampak bahwa S2 lemah dalam melakukan pelipatan jaring-jaring menjadi balok secara mental. Sesuai dengan Cohen \& Hegarty (2012), S2 memiliki kelemahan dalam visualisasi spasial dan relasi spasial. 


\section{Simpulan}

Penyusunan jaring-jaring merupakan aktivitas dalam belajar geometri yang mengaitkan antara bentuk dimensi dua dengan dimensi tiga. Meskipun terlihat sedehana namun eksplorasi terhadap pengonstruksian jaring-jaring sangat menarik untuk didalami karena banyak konsep yang perlu dipahami siswa. Studi ini mendeskripsikan penyusunan jaring-jaring yang dieksplorasi menggunakan sudut pandang kemampuan spasial. Tiga komponen kemampuan spasial digunakan sebagai dasar yaitu visualisasi, relasi dan orientasi spasial. Dapat disimpulkan bahwa dalam pengonstruksian jaring-jaring kubus dan balok, subjek mengalami kesulitan dikarenakan adanya kelemahan pada saat membayangkan jaring-jaring balok yang dilipat sehingga membentuk balok. Antara representasi dengan bayangan mental tidak sesuai. Kelemahan juga nampak dalam aktivitas mengaitkan atau merelasikan antar objek spasial, yaitu relasi antara unit persegi panjang dengan sisi yang berimpit harusnya memiliki panjang yang sama, namun dengan panjang yang tidak sama dianggap memiliki relasi berimpit dan membentuk rusuk dengan panjang yang sama. Dalam hal membayangkan objek yang dilihat dari sudut pandang berbeda juga masih lemah. Subjek tidak mengenali ketika terdapat dua jaringjaring yang kongruen tetapi dianggap tidak kongruen.

\section{Daftar Rujukan}

Cohen, C. A. \& Hegarty, M. (2012). J. Learning and Individual Difference 22 p 868 - 74

Cresswell, J. W. (2005). Educational Research (Boston, Pearson Education, Inc) p 7 - 11

Fraenkel. J. R, Wallen, N. E. \& Hyun, H, H. (2012). How to Design and Evaluate Research in Education (New York, McGraw-Hill) p 435 - 37

Gecu, Z \& Erkoc, M. F. (2015) Intr. J. Socials Science and Education 5580 - 89

Hawes, Z., Moss, J., Caswell, B. \& Poliszczuk, D. (2015). "Effects of Mental Rotation Training On Children's Spatial And Mathematics Performance: A Randomized Controlled Study". Trends in Neuroscience and Education http:/ / dx.doi.org/10.1016/j.tine.2015.05.001

Hegarty,M \& Waller, M. (2004). J. Intelligence 32 p 175 - 91

Jeon, K. (2009). Teaching Children Mathematic; p 394 - 99

Koyunkaya, M. Y. (2016). Intr. J. of Mathematic Education in Science and Technology 47 (7) p 1028-47

Mix,K. S, Levine, S. C, Cheng, Y. L, Young, C, Hambrick, D. Z \& Ping, R. (2016) J. of Experimental Psychology: General 145 (9) p 1206 - 27

Pittalis, M \& Christou. C. (2010). Education Stud Mathematic 75 p 191-212

Wai, J, Lubinski, D \& Benbow, C. P. (2009). J. of Educational Psychology 101 p 817

Wakabayashi, Y \& Ishikawa. T. (2011). J. Procedia Social and Behavioral Science 21 304-13

Yilmaz.B. (2009) Intr. Electronic J. of Elementary Education 1 (2) p 83-94 